\title{
Application of Process Skill Approach Combined with Cooperative Learning to Improve Students' Motivation and Achievement on Structure and Development of Plant I Subject
}

\author{
Astija \\ Universitas Tadulako \\ Palu, Indonesia \\ astijabiolog@untad.ic.id
}

\begin{abstract}
Applications of process skill approach and cooperative learning model to improve learning achievement of students have been studied. However, it is a little known on using the learning approach combined with the learning model. Therefore, this paper reveals a study on process skill approach combined with cooperative learning to improve motivation and learning achievement of students on structure and development of plant I subject. The study was implemented using classroom action research consisting of three cycles. Each cycle includes a planning, action, observation, and reflection. The data were analyzed with descriptive and inferential statistical tests. Results of the study showed that application of process skill approach and cooperative learning model could increase motivation and achievement of the students in the course. Aspects of the process skills done by the students during the lesson were observation, classification, interpretation, experiment design, communication, question, answering, refuse to answer, opinions, discussion, hypothesis and applying a concept or principle.
\end{abstract}

Keywords-process skill approach; cooperative learning; motivation; achievement

\section{INTRODUCTION}

The structure of plant development I course was early taught at semester 2 to be prerequisite and support for next level subjects such as High Plant Botany and Plant Physiology. The course contains the terms, concepts, and theories regarding the structure, character, and development of the plant. To learn the subject is highly required understanding and application of the actual plant concepts. Additionally, the subject is not only studied using observation but also it must be by operated using other skill aspects. Therefore, in teaching this course requires a special approach and appropriate learning model in order to obtain more effective teaching and satisfactory learning achievement.
Based on experience and observation and feedback of students to study the subject in Biology Education Studies Program, Tadulako University implementing conventionally with lecture was still unsatisfactory. The method seems to give less influence on motivation and achievement of the students. The learning motivation of the students was very low during the lecture due to a monotonous learning situation. In fact, motivation plays a very important in learning and can effect on learning achievement of students. A number of studies have reported that the motivation to learn has a positive and linear relationship with the learning achievement [1]-[6]. Furthermore, motivation does not only come from the students themselves (intrinsic motivation) but also the motivation is given by the teacher (extrinsic motivation). Both intrinsic and extrinsic motivations play a role to improve learning achievements [1], [6] - [9]. If strong motivation is on a student, it certainly will have a positive impact on student learning achievements.

In addition to low motivation, also found that the students' ability to receive knowledge and understanding of the course is quite low, as illustrated by a number of the students who fail the course. This is most likely due to the use of methods that are less precise. During the learning process, lecturer used a lecture or information-discussion method only. Replacement of the method by giving assignments and group work has been conducted. On the other hand, use of visual media in learning to use power point has been attempted by the lecturer but the results are not still satisfactory. Therefore, selected approach and learning model that matches the characteristics of the student and the course are required to increase the student motivation in learning.

One of approach learning in science is learning applying process skill approach. Process skills approach is an approach to learning that is more emphasis on the ability of students performing processes of search, discovery, exploration concepts, principles, theories and problem solving for the science [1], [2]. In conducting the processes that students are expected to use all five senses, not just one or two senses such as in learning with lectures. In process skill learning approach, students are expected to reconstruct new knowledge by using 
prior knowledge or learning experience such as General Biology Course. The use of process skill approach is in line with a theory that students have some knowledge and skills that of which must be developed to meet new knowledge and skills [3]. As such, aspects of process skills are required and developed in teaching-learning processes in order to the students gain not only the products of sciences but also process skills.

Compared to expository approach that demands the mastery of learning materials, process skill approach requires the ability of students to use the process skills of sciences to obtain the desired knowledge. Another word, the knowledge might be discovered by the process skill aspects such as; observation, classification, interpretation, experimental design, communication, question, answering, refuse answering, opinion, discussion, hypothesis, applying the concept or principle. The aspects of these processes are very important skills needed in the learning of sciences to get the concepts, principles, theories, and laws of science. Therefore, this approach seems particularly relevant to learning principles of science are more stressed to solving the problem with the scientific method. This is in line with the character of the process skills approach that this approach was developed so that students have a scientific attitude as scientists in finding a concept or skill-process theories.

To have maximal results of the process skill aspects, it might be much better the learning approach combined with cooperative learning model. Learning with this model, students attempted to work together in various learning activities of their knowledge. During the interaction with other students, the students are expected to appear various aspects of process skills.

Using process skill approach combined with cooperative learning model is hypothesized to solve the problem of low motivation and learning outcomes of students in the structure and development of plants I subject. Therefore, this paper reveals that application of process skill approach and cooperative learning model to improve motivation and achievement learning.

\section{METHOD}

The study was conducted using a classroom action research with three cycles. Each cycle consists of the preparation stage of action, action execution, observation and reflection of the implementation of the action [4], [5]. The action plan was done by reconstructing the syllabus and lesson plans, composing a motivation sheet consisting of 6 questions, compiling a list of 12 aspects of process skills and organizing assessment with 5 essay questions for each learning cycle. Implementation of the action was done by carrying out teaching and learning activities in the classroom in accordance with the learning plan. During the implementation of the action, student activities on the aspects of process skills were observed using the observation sheet. The aspects of process skills were scored from zero for students who did not do up to score 4 for students who did perfectly it. The aspects of process skills observed were aspects of observing, classifying, interpreting, hypothesizing, designing experiments, communicating, asking questions, answering questions, refuting answers, expressing opinions, discussing, and applying concepts/theories. At the end of the implementation of the action, it was carried out a test (assessment) to obtain learning results. Additionally, it was given a questionnaire to determine the level of student learning motivation.

The data obtained about the aspects of process skills, motivation and student learning achievement during teaching and learning activities were analyzed with descriptive statistics such as mean, standard deviation, minimum and maximum. After that, those were tested with ANOVA and followed by an LSD test. All of these tests were needed to describe the events that occurred during the learning process and to reflect on the successful lesson that has been implemented. The reflection referred to the established successful indicator in that aspect of the process skills have been done by all students with an average of more than 5 times of every aspect. In addition, student learning achievements had reached a classical average of 70 and student motivation was quite high.

\section{RESULT AND DISCUSSION}

Research on the application of process skill approach combined with the cooperative learning model on the course of structure and development of plant I in cycle 1 was attended by 37 of 40 students. The students were divided into 6 groups consisting of 6 students except for 1 group of 7 persons. During the course, the students were involved in a number of activities to perform process skills with the results as shown in Fig. 1.

The Fig. 1 showed that the activities of the process skill aspects in cycle 1 were dominantly conducted by students on the aspects of observing and discussions with 23.89 and 27.73 averages, respectively. While other aspects of process skills ranged from 9 to 15 times. In this cycle, there were some aspects of process skills that had not been done by the students being interpreting, designing experiment, refuting answer, asking a question and applying the concept/principle.

Aspects of process skills were still very low and the fifth aspects of process skills that had not been done by students in cycle 1 were probably due to changes in the teaching situation of learning using the conventional lecture approach to the learning by using process skills combined with a cooperative model. Generally, the change from an old to the new condition required a process of adaptive behavior. Several studies suggested that the adaptive process usually took customization capabilities, and sensory-motor skills and behavior in response to things or new situations [6], [7]. In addition, it might be caused by an ability of lecturer in applying the learning model and approach in the course was not accustomed to that the lecturer was more dominating than a student in the learning. In another word, the lecturer centered learning was dominantly conducted by lecturer than by student. As such, the learning resulted in a lack of activity, a low motivation, and student learning achievement. This case was in line with several 
studies that had been done that student-centered learning could improve motivation [8] and learn achievement [9]. Even, students could easily construct an understanding through their previous learning experience [10].

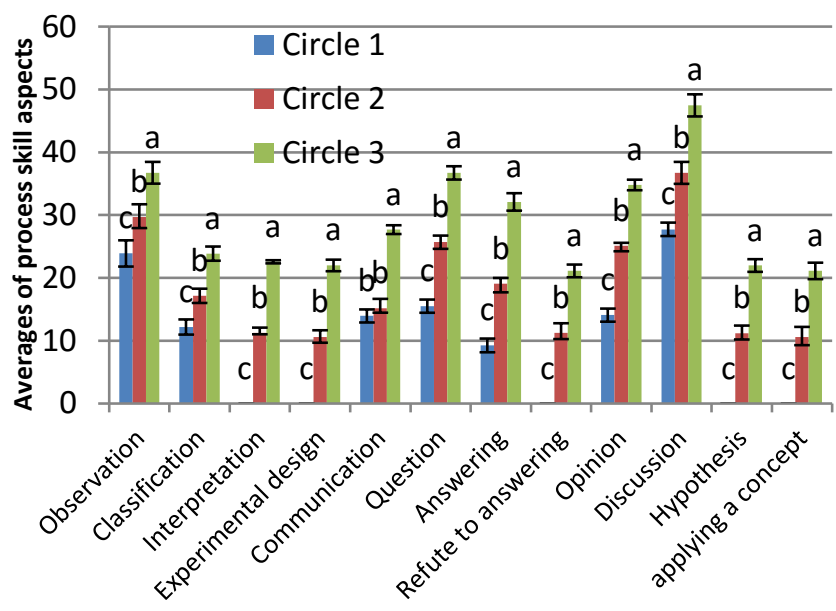

Fig. 1. Aspects of process skills were observed for 3 cycles. There were five aspects of process skills that had not been done by students in cycle 1 . Aspects of process skills increased significantly from cycle 1 to 2 to 3 . Data were mean \pm SD. Different letters indicated statistically significant differences based on ANOVA followed LSD analyses at $\alpha=0.05$.

Another interesting result obtained during learning in cycle 1 was that the learning environment was conducive, although it was still required to be improved. This atmosphere occurred because the students conducted learning activities in groups to individually perform activities of process skills. The conducive learning environment was based on a learning atmosphere of comfort, order, liveliness, calm and smoothness during the learning in the classroom. Conducive learning atmosphere was urgently required in learning so that the students could do their learning experiences to gain good achievement learning. Many studies reported that learning environment was needed to improve learning achievement [6]-[10]. In this result, activities of process skills created a conducive environment for the learning because the students did not have a chance to do the activities of not learning in the classroom. Some reports stated that learning atmosphere was usually not conducive when students did non-learning activities in the classroom resulting in interfering the learning [8], [11].

Conducive atmosphere occurred in learning of the cycles 1 was accompanied by a sufficient motivation of the students. Student motivation was observed based on responses to a questionnaire. The all of the respondents stated that they prefer a learning model and approaches used. Several reasons were as follow: 1) the learning model and approach used was different from previous learning model and approach, 2) The model and approach was quite fun because of working together in a group, 3) The students actively learned various process skill activities that of was useful in studying sciences (called, intrinsic motivation) and were obtaining a high achievement (called, extrinsic motivation) in learning activities. As result, the internal and external motivation impacted on the creation of a conducive atmosphere for learning, process skill activities and learning achievement. These interesting results were new insights found in the learning of the cycle 1 . The result supported to previous studies reporting that motivation affected learning achievement [11] - [13].

Unfortunately, the motivation obtained in the cycle 1 was still quite low. This low motivation impacted on learning achievement of the students. Based on the assessment performed by using the essay test, there were 16 students of 34 students who master the topic learning whereas 18 students were still undesirable achievements. In this cycle, there were 34 students attending the learning, there were 6 people who were absent. Thus, level of classical learning completeness was $47.06 \%$ (see Fig. 2), indicating that this evaluation was still very unsatisfactory in which successful indicators of the proposed study achievement was $80 \%$. Furthermore, this study should be continued to the second cycle.

In cycle 2, aspects of process skills performed by the students increased significantly (see Fig. 1). Even, the absence of fifth process skill aspects in cycle 1 , had been done by the students in cycle 2. Other things were that conducive atmosphere and student motivation in learning were also much better, compared to that of the learning cycle 1 . However, these should be improved. Therefore, evaluation and reflection of the action were emphasized on how aspects of the process skills were improved. Efforts conducted to improve the process skill aspects were projected into cycle 3 as follow:

- To repair learning plans. Learning plans were improved on parts of the learning activities, particularly on core activities of teaching-learning processes. At the core activities, lecturer provided the observation sheets to the student before starting learning and students were asked to read carefully the observation sheets.

- To repair the observation sheet format about aspects of process skills. The observation sheet should be filled and recorded by the students. The reasons were because of difficulties of the lecturer in observation and recording. However, the lecturer checked the student-done observation and recording. As result, the teaching-learning process in the cycle 2 was more enjoyable, comfortable, active and successful than that in the cycle 1 .

Results of learning evaluation in cycle 2 showed that there were 30 students who had mastered the learning, while 8 of other students had not been unsatisfactory. The other word, there was $78.94 \%$ of the students completing the lesson at the targeted level or learning indicator. This result was almost achieved because the targeted level indicator that was $80 \%$. Therefore, the study had to be still continued in the third cycle.

In cycle 3, all aspects of the process skills undertaken by the students increased significantly, compared with cycle 1 and 2 the results (see Fig. 1). Enhancements of the activities of 
the process skills aspects positively impacted on learning achievements, in addition to conducive environmental learning and motivation. In fact, the result of the evaluation implemented in the cycle was that there were 38 of 40 students had mastered the learning while two students were still unresolved. This result recommended that mastery of learning was $95 \%$ (Fig. 2), exceeding the targeted indicators in this study in that $80 \%$.

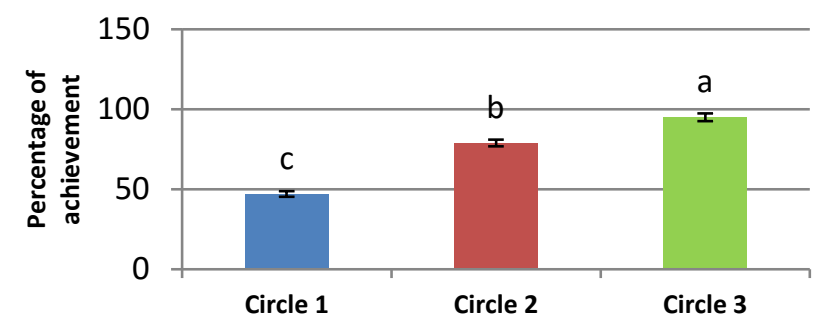

Fig. 2. Learning achievements of students were obtained for 3 cycles. The learning achievements increased significantly from cycle 1 to 2 to 3 . Data were mean \pm SD. Different letters indicated statistically significant differences based on ANOVA followed LSD analyses at $\alpha=0.05$.

skill activities started from cycle 1 to 2 to 3 . Increasing of the process skill activities was correlated with the learning achievement. These results were similar to studies conducted earlier that aspects of process skills increased from cycle 1 to next cycle in a General Biology [12] and Biology Cells Learning [13]. However, the interesting result was that an increase in process skill activities was also associated with increasing of motivation and conducive atmosphere for learning. These are very important and necessary for the learning.

\section{CONCLUSION}

Application of process skills approach combined with cooperative learning model can improve student motivation and learning achievement in structure and development of plant I course, in addition to creating a conducive learning. Aspects of process skills done by students include; observing, classifying, interpreting, designing experiments, communicating, asking questions, answering questions, refuting answers, opinions, discussing, hypothesizing and applying concept/principle.

\section{REFERENCES}

[1] S. Erkol and I. Ugulu, "Examining Biology Teachers Candidates' Scientific Process Skill Levels and Comparing these Levels in Terms of Various Variables," Procedia - Soc. Behav. Sci., vol. 116, pp. 4742-4747, 2014.

[2] J. Marjan, I. B. P. Arnyana, and I. G. a N. Setiawan,
"Pengaruh Pembelajaran Pendekatan Saintifik Terhadap Hasil Belajar Biologi dan Keterampilan Proses Sains Siswa MA Mu' allimat NW Pancor Selong Kabupaten Lombok Timur Nusa Tenggara Barat," J. Pendidik. IPA, vol. 4, no. 1, pp. 1-12, 2014.

[3] Z. Aziz, R. Majzub, N. Nordin, and K. M. Noor, "Improvement in the mastery of answering science process skill questions through self-learning module," Res. J. Appl. Sci., vol. 7, no. 7, pp. 365-369, 2012.

[4] S. Kemmis and R. McTaggart, "Participatory action research: Communicative action and the public sphere," Strategy. Qual. Inq., pp. 271-330, 2007.

[5] S. Kemmis, R. McTaggart, and R. Nixon, "The action research planner," Action Res. Plan. Doing Crit. Participate. Action Res., no. Carr 2006, p. 154, 2014.

[6] C. M. Rodriguez, "The impact of academic selfconcept, expectations and the choice of learning strategy on academic achievement: the case of business students," High. Educ. Res. Dev., vol. 28, no. 5, pp. 523-539, 2009.

[7] V. Bartsch, M. Ebers, and I. Maurer, "Learning in project-based organizations: The role of project teams' social capital for overcoming barriers to learning," Int. J. Proj. Manag., vol. 31, no. 2, pp. 239-251, 2013.

[8] A. Singh, "Conducive Classroom Environment in Schools," Int. J. Sci. Res., vol. 3, no. 1, 2014.

[9] N. B. Adams, T. A. DeVaney, and S. G. Sawyer, "Measuring Conditions Conducive to Knowledge Development in Virtual Learning Environments: Initial Development of a Model-Based Survey," J. Technol. Learn. Assess., vol. 8, no. 1, pp. 1-24, 2009.

[10] S. S. Ahmad, M. F. Shaari, R. Hashim, and S. Kariminia, "Conducive Attributes of Physical Learning Environment at Preschool Level for Slow Learners," Procedia - Soc. Behav. Sci., vol. 201, pp. 110-120, 2015.

[11] C. Gorelick, "Organizational learning vs the learning organization: a conversation with a practitioner," Learn. Organ., vol. 12, no. 4, pp. 383-388, 2005.

[12] Astija, "Penerapan pendekatan ketrampilan proses dalam pembelajaran Biologi Umum. Kreatif, vol. 12, pp. 1-13, 2009.

[13] Astija, "Penerapan pendekatan ketrampilan proses dalam pembelajaran Biologi Sel," MEDIA EKSAKTA, vol. 5, pp. 32-37, 2009. 